\title{
Flowering of Woody Bamboo in Tissue Culture Systems
}

\author{
Jin-Ling Yuan ${ }^{1}$, Jin-Jun Yue ${ }^{1}$, Xiao-Ping Gu ${ }^{1}$ and Choun-Sea Lin ${ }^{2 *}$ \\ ${ }^{1}$ Research Institute of Subtropical Forestry, Chinese Academy of Forestry, Hangzhou, China, ${ }^{2}$ Agricultural Biotechnology \\ Research Center, Academia Sinica, Taipei, Taiwan
}

Flowering and subsequent seed set are not only normal activities in the life of most plants, but constitute the very reason for their existence. Woody bamboos can take a long time to flower, even over 100 years. This makes it difficult to breed bamboo, since flowering time cannot be predicted and passing through each generation takes too long. Another unique characteristic of woody bamboo is that a bamboo stand will often flower synchronously, both disrupting the supply chain within the bamboo industry and affecting local ecology. Therefore, an understanding of the mechanism that initiates bamboo flowering is important not only for biology research, but also for the bamboo industry. Induction of flowering in vitro is an effective way to both shorten the flowering period and control the flowering time, and has been shown for several species of bamboo. The use of controlled tissue culture systems allows investigation into the mechanism of bamboo

OPEN ACCESS

Edited by:

Chi-Kuang Wen,

Shanghai Institutes for Biological

Sciences (CAS), China

Reviewed by:

Yulong Ding,

Nanjing Forestry University, China Hong-Hwa Chen, National Cheng Kung University,

Taiwan

*Correspondence:

Choun-Sea Lin

cslin99@gate.sinica.edu.tw

Specialty section:

This article was submitted to

Plant Physiology,

a section of the journal

Frontiers in Plant Science

Received: 23 June 2017

Accepted: 30 August 2017

Published: 14 September 2017

Citation:

Yuan J-L, Yue J-J, Gu X-P and Lin C-S (2017) Flowering of Woody Bamboo in Tissue Culture Systems.

Front. Plant Sci. 8:1589.

doi: 10.3389/fp/s.2017.01589 flowering and facilitates selective breeding. Here, after a brief introduction of flowering in bamboo, we review the research on in vitro flowering of bamboo, including our current understanding of the effects of plant growth regulators and medium components on flower induction and how in vitro bamboo flowers can be used in research.

Keywords: flowering induction, in vitro seed set, in vitro hybridization, bamboo reproduction, plant growth regulators

\section{INTRODUCTION}

Flowering, fruiting, and seed development are the most fundamental processes of sexual propagation in plants. Most flowering plants pass from seed germination to a brief period as a seedling, to a vegetative or juvenile phase that is predominated by growth, and then onto a reproductive phase, during which plants have the capacity to produce the components required for flowering and seed production (Huijser and Schmid, 2011). The length of the plant juvenile phase varies widely. Usually, herbaceous plants have a short juvenile phase (within 1-2 seasons), complete their life cycle within a few years, and die after seed production (Feng et al., 2016). However, woody plants have a long juvenile phase (many years), remain alive after flowering, and can flower every year after reaching maturity (Wendling et al., 2014a,b).

Compared with these two types of plants, woody bamboos which were identified as monopodial with leptomorph rhizome (Figures 1A,C) and sympodial with pachymorph rhizome (Figures 1B,D; McClure, 1966), have a unique flowering behavior. Woody bamboos have a very long juvenile phase (decades), similar to woody plants. However, woody bamboo only flowers once and dies after seed production (monocarpy) (McClure, 1966; Janzen, 1976).

There are advantages and disadvantages to this unique flowering behavior, particularly for the bamboo industry. During the long vegetative phase, bamboo stalks (building materials) and young shoots (edible vegetable) can be continually harvested for many years. Propagation costs can be 
reduced in bamboo species that grow by rhizomes, such as monopodial bamboos, yielding an entire plantation composed of plants of the same genetic background. These monoculture plantations consist of plants initiated at the same time and often flower en masse, disrupting the supply chain and causing huge economic losses. This gregarious flowering not only takes that plantation out of service (Sarma et al., 2010) but also causes ecological and enviromental challenges. For example, a bamboo grove that has recently flowered does not provide food for the giant panda (Li and Denich, 2004). Furthermore, once fruit has set, this new food source can lead to overpopulation of rats, which in the past have over-consumed the seeds, leaving the bamboo forest unrecovered (Nag, 1999).

Since it is difficult to predict flowering time and to time the flowering of two bamboo accessions for hybridization, it is difficult for breeders to use select varieties for bamboo breeding (John and Nadgauda, 1999; Singh et al., 2013). Without genetic recombination through cross-pollination, genome diversity is limited and genetic studies are nearly impossible. Furthermore, bamboo classification is debated and confusing since plant taxonomy often relies on the morphology and anatomy of flowers and fruits and speciation depends on sexual incompatibility (Bhattacharya et al., 2006, 2009).

Over the years, many researchers have tried to manipulate bamboo flowering not only for research and industrial purposes but also to manage the environmental impact. Because of the size of woody bamboo, it is difficult to establish controlled environments for scientific research. The first case of in vitro bamboo flowering and seed production was reported less than 30 years ago (Nadgauda et al., 1990). Compared with in vivo flowering, there are many advantages to in vitro flowering. Firstly, the plantlets can be incubated in a sterile, controlled environment, which can reduce interference from biotic and abiotic stresses and uncontrolled pollination. Secondly, the size of the plantlet is relatively small within the incubation container, allowing addition of plant growth regulators to the whole plantlet. Thirdly, flowering can be induced when desired. Here, we review recent reports on in vitro bamboo flowering.

\section{FLOWER INDUCTION IN VITRO: SPECIES AND EXPLANT TYPES}

To date, 13 bamboo species have been induced to flower in vitro (Table 1). Five of the species belong to the genus Bambusa: B. arundinacea (Nadgauda et al., 1990, 1997; Ansari et al., 1996; Joshi and Nadgauda, 1997), B. edulis (Lin and Chang, 1998, Figure 1E), B. multiplex (Prutpongse and Gavinlertvatana, 1992), B. oldhamii (Ho and Chang, 1998; Zhang and Wang, 2001), and B. vulgaris (Rout and Das, 1994). Six of the species belong to the genus Dendrocalamus: D. brandisii (Nadgauda et al., 1990), D. giganteus (Rout and Das, 1994; Ramanayake et al., 2001), D. hamiltonii (Chambers et al., 1991; Kaur et al., 2015), D. latiflorus (Zhang and Wang, 2001; Lin et al., 2006, 2007b), D. membranaceus (Prutpongse and Gavinlertvatana, 1992), and D. strictus (Rout and Das, 1994). The last two accessions are Cephalostachyum pergracile (Prutpongse and Gavinlertvatana, 1992) and an intergenus hybrid, B. pervariabilis $\times$ D. latiflorus (Zhang and Wang, 2001). Based on these reports, all the bamboo species that have been shown to flower in vitro are sympodial bamboos. There has not been a report on in vitro flowering for a monopodial bamboo. Actually, there are only few reports on monopodial bamboo tissue culture (Gielis, 1999; Wang et al., 2005; Pei et al., 2011; Mudoi et al., 2013; Yuan et al., 2013), regardless of its better cold-tolerance and other merits over sympodials. Although Hassan and Debergh (1987) originally reported tissue culture protocols for $P$. viridis, they retracted the article because of a taxonomy issue. Therefore, work remains to be done to develop in vitro flowering tissue culture protocols for important monopodial species.

Different species showed different responses in the same medium. In medium supplemented with 6-benzylaminopurine (BA) and coconut milk, B. arundinacea showed a $70 \%$ flowering rate, $D$. brandisii only $40 \%$, and D. strictus did not flower (Nadgauda et al., 1990). D. brandisii and Dendrocalamopsis oldhamii $(=B$. oldhamii) did not flower in a medium that could induce flowering in $B$. pervariabilis $\times D$. latiflorus (Zhang and Wang, 2001). B. edulis flowered in a medium supplemented with $0.1 \mathrm{mg} / \mathrm{L}$ thidiazuron (TDZ), but B. oldhamii only proliferated multiple shoots (Lin and Chang, 1998; Lin et al., 2007a). Those reports indicated that different species will not induce flowering in a uniform medium, and the medium components for certain bamboo must be screened through purposely designed experiments.

The time to in vitro flowering also varies between different species, across a range including 45 days (B. arundinacea, Ansari et al., 1996), just under 12 months (B. edulis, Lin and Chang, 1998), 29 months (D. giganteus, Ramanayake et al., 2001), and three years (D. latiflorus, Zhang and Wang, 2001). Although it still takes years for some of the bamboos to flower, in vitro culture nevertheless dramatically reduces bamboo flowering times compared to those in the field.

Another key factor in in vitro flowering is the choice of explant used to establish the in vitro culture and the explant selected for subsequent micropropagation. Current protocols use shoot meristems (Lin and Chang, 1998; Ramanayake et al., 2001; Lin et al., 2010) and seedlings (Nadgauda et al., 1990, 1997; Chambers et al., 1991; Ansari et al., 1996; Joshi and Nadgauda, 1997; Singh et al., 2000; Zhang and Wang, 2001). However, sourcing of seeds is not predictable, and bamboo seeds often do not have unique or widely diverse genetic backgrounds. The use of meristems from superior bamboo lines is a better strategy that will support bamboo breeding.

\section{FLOWER INDUCTION IN VITRO: CONTROL BY PLANT GROWTH REGULATORS}

Plant growth regulators are critical to in vitro bamboo flowering. In vitro flowering of bamboo can be induced by cytokinins, as has been shown in D. brandisii (Nadgauda et al., 1990), D. giganteus (Rout and Das, 1994; Ramanayake et al., 2001), D. hamiltonii (Chambers et al., 1991), D. latiflorus (Zhang and Wang, 2001; Lin 

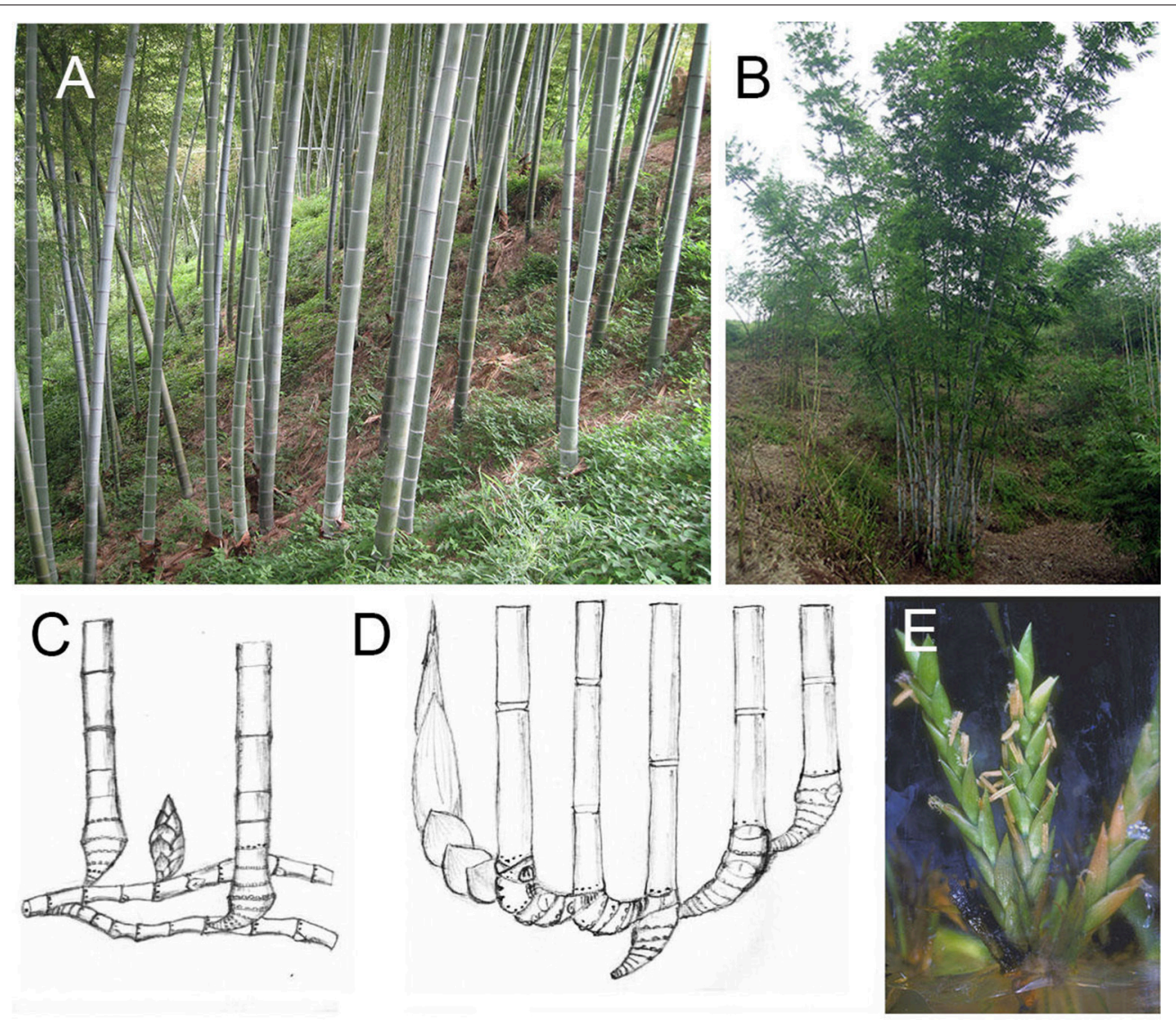

FIGURE 1 | Stalks, rhizomes, and flower of monopodial and sympodial bamboo. (A) Stalks of a monopodial bamboo (P. edulis). (B) Stalks of a sympodial bamboo (B. chungii). (C) Rhizome of monopodial bamboo. (D) Rhizome of sympodial bamboo. (E) Flower in tissue culture system of a sympodial bamboo (B. edulis).

et al., 2007b), D. strictus (Rout and Das, 1994; Singh et al., 2000), B. arundinacea (Nadgauda et al., 1990, 1997; Joshi and Nadgauda, 1997), B. edulis (Lin and Chang, 1998; Lin C. C. et al., 2003), B. multiplex (Prutpongse and Gavinlertvatana, 1992), and $B$. vulgaris (Rout and Das, 1994, Table 1). The effects of cytokinins on in vitro bamboo flowering are species dependent. For example, kinetin (Kin) could not induce flowering in B. arundinacea (Joshi and Nadgauda, 1997) or D. latiflorus (Zhang and Wang, 2001), but could for B. edulis plantlets with multiple shoots (Lin C. C. et al., 2003). Similar positive results were observed with zeatin (ZT) treatment of B. arundinacea and B. edulis (Joshi and Nadgauda, 1997; Lin C. S. et al., 2003). In B. arundinacea, flowering only occurred in medium containing BA combined with either ZT, adenine sulfate (Ads), Kin, or isopentyl adenine (2iP), but not those containing only one of the listed cytokinins without BA (Joshi and Nadgauda, 1997). D. strictus could not flower with $5 \mathrm{mg} / \mathrm{L} \mathrm{BA}$ alone (Nadgauda et al., 1990), but a combination of cytokinin (Ads), auxin [Indole-3-butyric acid (IBA)] and Gibberellic acid $\left(\mathrm{GA}_{3}\right)$ could induce flowering and seed formation (Rout and Das, 1994). In B. edulis, cytokinins are important not only for flower induction but also for inflorescence proliferation (Lin C. S. et al., 2003). The inflorescences could multiply when treated with different kinds of cytokinins, such as BA (Lin et al., 2004b). According to these results, cytokinins play positive roles in bamboo flowering.

Interestingly, auxins play an opposite role in bamboo flowering. In medium containing $0.1 \mathrm{mg} / \mathrm{L} \mathrm{TDZ,} \mathrm{flowering}$ of $B$. edulis plantlets with multiple shoots was inhibited by naphthaleneacetic acid (NAA) (Lin C. S. et al., 2003). When using in vitro inflorescences as explants, auxin-only medium increased the floret size, and also induced adventitious roots and caused $35 \%$ more vegetative shoots to emerge. These rooted vegetative plantlets could be transplanted to the greenhouse and survive (Lin et al., 2005). These results indicated that auxin plays a negative role in bamboo flowering and inflorescence proliferation in vitro.

Other plant growth regulators and medium components have also been investigated, such as the ethylene precursor 1amino-cycliopropane-1-carboxylic acid (ACC), acetic salicylic acid, gibberrellin, the gibberrellin synthesis inhibitor ancymidol (Lin, 1998), coconut water (Zhang and Wang, 2001), sucrose, nitrogen at various concentrations (Lin C. C. et al., 2003), and the $\mathrm{pH}$ of the medium (Joshi and Nadgauda, 1997). These treatments led to only slight effects on flower induction. 
TABLE 1 | In vitro flowering of bamboo species: explant types, medium components, and results.

\begin{tabular}{|c|c|c|c|c|c|}
\hline Species & Explant & Medium & Induction time & Main results & References \\
\hline $\begin{array}{l}\text { Bambusa arundinacea, } \\
\text { Dendrocalamus } \\
\text { brandisii, D. strictus }\end{array}$ & Seedling & $\begin{array}{l}\mathrm{MS}+2 \% \text { sucrose }+5 \\
\mathrm{mg} / \mathrm{L} \mathrm{BA}+50 \mathrm{ml} / \mathrm{L} \\
\mathrm{CW}\end{array}$ & & $\begin{array}{l}70 \% \text { B. arundinacea and } 40 \% \\
\text { D. brandisii flowered, and fertile seeds } \\
\text { produced. }\end{array}$ & $\begin{array}{l}\text { Nadgauda et al., } \\
1990\end{array}$ \\
\hline B. arundinacea & Seedling & $\begin{array}{l}\mathrm{MS}+3 \% \text { sucrose }+ \\
0.7 \% \text { agar }+2 \mathrm{mg} / \mathrm{L} \\
\mathrm{BA}+3 \mathrm{mg} / \mathrm{L} \text { NAA }\end{array}$ & $\begin{array}{l}\text { Rooting at } 10 \\
\text { days. Flowering } \\
\text { at } 45 \text { days. }\end{array}$ & $\begin{array}{l}\text { Peroxidase depressed prior to } \\
\text { appearance of root and flower primordia. }\end{array}$ & Ansari et al., 1996 \\
\hline B. arundinacea & Seedling & $\begin{array}{l}\mathrm{MS}+2 \% \text { sucrose }+ \\
2.22 \mu \mathrm{M} \text { BA, or with } \\
0.26 \mu \mathrm{M} \text { ZT, } \\
2.71-271.0 \mu \mathrm{M} \text { AdS, } \\
2.32-9.30 \mu \mathrm{M} \mathrm{Kin,} 4.9 \\
\mu \mathrm{M} 2 \mathrm{PP}\end{array}$ & & $\begin{array}{l}\text { In vitro florets had all floral parts. BA was } \\
\text { the only cytokinin to induce flowering, } \\
\text { either individually or with others (ZT, AdS, } \\
\text { Kin, 2iP). Root elongation and flower } \\
\text { induction had an inverse relationship. }\end{array}$ & $\begin{array}{l}\text { Joshi and } \\
\text { Nadgauda, } 1997\end{array}$ \\
\hline B. edulis & $\begin{array}{l}\text { 10-year-old } \\
\text { field-grown } \\
\text { nodal explants }\end{array}$ & $\mathrm{MS}+0.1 \mathrm{mg} / \mathrm{L} \mathrm{TDZ}$ & 8 months & $\begin{array}{l}\text { Spikelets and florets normal, no seed } \\
\text { set, no viable pollen produced. A potted } \\
\text { plant flowered and survived after } \\
\text { flowering. }\end{array}$ & $\begin{array}{l}\text { Lin and Chang, } \\
1998\end{array}$ \\
\hline B. edulis & Inflorescence & $\begin{array}{l}\mathrm{MS}+0.1 \mathrm{mg} / \mathrm{L} \mathrm{TDZ}+ \\
30 \mathrm{~g} / \mathrm{L} \text { sucrose }\end{array}$ & $\begin{array}{l}10 \text { months, } \\
\text { subcultured } \\
\text { every } 21 \text { days }\end{array}$ & Inflorescence proliferated, pollen sterile. & $\begin{array}{l}\text { Lin C. S. et al., } \\
2003\end{array}$ \\
\hline B. edulis & In vitro spikelet & $\begin{array}{l}\text { MS + } 0.5 \mu \mathrm{M} \text { TDZ, or } \\
23.2 \mu \mathrm{M} \text { Kinetin, or } \\
16.2 \mu \mathrm{M} \text { BPA, or } 22.2 \\
\mu \mathrm{M} \mathrm{BA} \text {, or } 22.8 \mu \mathrm{M} \mathrm{ZT}, \\
+30 \mathrm{~g} / \mathrm{L} \text { sucrose }\end{array}$ & 21 days & $\begin{array}{l}\text { Cytokinins were effective in flower } \\
\text { induction, but NAA was a negative } \\
\text { regulator. Rooted plantlets with } \\
\text { vegetative shoots, even though they had } \\
\text { flowers, could survive and grow well as } \\
\text { normal plants without hardening after } \\
\text { transplant to greenhouse. }\end{array}$ & $\begin{array}{l}\text { Lin C. C. et al., } \\
2003\end{array}$ \\
\hline B. edulis & Inflorescence & $\mathrm{MS}+0.1 \mathrm{mg} / \mathrm{L} \mathrm{TDZ}$ & $\begin{array}{l}\text { Long-term } \\
\text { proliferation }\end{array}$ & $\begin{array}{l}\text { TDZ, but not } \mathrm{GA}_{3}, \mathrm{ABA} \text {, or } \mathrm{ACC} \text { alone, } \\
\text { was efficient in inducing inflorescence } \\
\text { proliferation. }\end{array}$ & Lin et al., 2004b \\
\hline B. edulis & Inflorescence & $\begin{array}{l}\mathrm{MS}+5 \mathrm{mg} / \mathrm{L} \mathrm{NAA} ; \mathrm{MS} \\
+5 \mathrm{mg} / \mathrm{L} \mathrm{NAA}+1 \\
\mathrm{mg} / \mathrm{L} \mathrm{ACC}\end{array}$ & 2 months & $\begin{array}{l}\text { NAA, IBA, } 2,4-D \text { induced vegetative } \\
\text { shoots. } 50 \% \text { of shoots flowered in MS + } \\
5 \text { mg/L NAA, and all flowered in MS + } 5 \\
\text { mg/L NAA + } 1 \text { mg/L ACC. All rooted } \\
\text { plantlets survived after transplanting in } \\
\text { greenhouse. }\end{array}$ & Lin et al., 2005 \\
\hline B. oldhamii & $\begin{array}{l}\text { Eleven- year old } \\
\text { embryogenic } \\
\text { cell line }\end{array}$ & $\begin{array}{l}\mathrm{MS}+3 \mathrm{mg} / \mathrm{L} 2,4-\mathrm{D}+ \\
2 \mathrm{KT}+6 \% \text { sucrose }\end{array}$ & & $\begin{array}{l}\text { Five percent albino plantlets flowered } \\
\text { and produced viable pollen. Seventy five } \\
\text { percent of the pollen was fertile. }\end{array}$ & $\begin{array}{l}\text { Ho and Chang, } \\
1998\end{array}$ \\
\hline $\begin{array}{l}\text { B. pervariabilis } \times \\
\text { D. latiflorus, } D \text {. latiflorus }\end{array}$ & $\begin{array}{l}\text { Seedling of } \\
D \text {. latiflorus, } \\
\text { nodal explants } \\
\text { of } B \text {. } \\
\text { pervariabilis } \times \\
D \text {. latiflorus }\end{array}$ & $\begin{array}{l}3 / 4 \mathrm{MS}+2-4 \mathrm{mg} / \mathrm{L} \mathrm{BA} \\
+0.5-1.0 \mathrm{mg} / \mathrm{L} \mathrm{KT}+ \\
100 \mathrm{ml} / \mathrm{L} \mathrm{CW}\end{array}$ & $1-3$ years & $\begin{array}{l}\text { Seedling clones of } D \text {. latiflorus with } \\
\text { strong shoot-emerging ability were easily } \\
\text { induced to flower. BA was effective in } \\
\text { inducing flowering. KT was helpful for } \\
\text { vegetative growth. }\end{array}$ & $\begin{array}{l}\text { Zhang and Wang, } \\
2001\end{array}$ \\
\hline $\begin{array}{l}\text { B. vulgaris, } \\
\text { D. giganteus, D. strictus }\end{array}$ & $\begin{array}{l}\text { Nodal explants } \\
\text { from somatic } \\
\text { embryo-derived } \\
\text { plants }\end{array}$ & $\begin{array}{l}\mathrm{MS}+0.5 \mathrm{mg} / \mathrm{L} \text { Ads }+ \\
0.25 \mathrm{mg} / \mathrm{L} \mathrm{IBA}+0.5 \\
\mathrm{mg} / \mathrm{L} \mathrm{GA} \mathrm{A}_{3}+3 \% \\
\text { sucrose }\end{array}$ & 12 weeks & $\begin{array}{l}\text { In vitro flowering was achieved. About } \\
\text { 10-12 viable seeds were obtained from } \\
\text { each culture of } D \text {. strictus and } \\
\text { D. Giganteus; B. vulgaris produced 3-4 } \\
\text { seeds per culture. }\end{array}$ & $\begin{array}{l}\text { Rout and Das, } \\
1994\end{array}$ \\
\hline
\end{tabular}


TABLE 1 | Continued

\begin{tabular}{|c|c|c|c|c|c|}
\hline Species & Explant & Medium & Induction time & Main results & References \\
\hline D. giganteus & $\begin{array}{l}\text { Adult bamboo } \\
\text { node segment }\end{array}$ & $\begin{array}{l}\mathrm{MS}+2 \% \text { sucrose }+ \\
3-6.0 \mathrm{mg} / \mathrm{L} \mathrm{BA}+0.1 \\
\mathrm{mg} / \mathrm{L} \mathrm{KT}\end{array}$ & 29 months & $\begin{array}{l}\text { The lemma tapered to a point and the } \\
\text { margins opened out. Spikelets were } \\
\text { narrow and long. Stamens ranged from } \\
0 \text { to } 12 \text {. Anthers did not dehisce. } \\
\text { Microspores were empty. Neither the } \\
\text { style nor the stamens elongated as in } \\
\text { the field. No seed set. }\end{array}$ & $\begin{array}{l}\text { Ramanayake } \\
\text { et al., } 2001\end{array}$ \\
\hline D. hamiltonii & $\begin{array}{l}\text { In vitro shoots } \\
\text { from somatic } \\
\text { embryo derived } \\
\text { plants }\end{array}$ & $\begin{array}{l}\mathrm{MS}+2 \% \text { sucrose }+ \\
0.5 \mathrm{mg} / \mathrm{L} \mathrm{BAP}+0.25 \\
\mathrm{mg} / \mathrm{L} \mathrm{IBA}\end{array}$ & $14-35$ days & $\begin{array}{l}\text { Flowering induced from } 27-80 \% \text { of } \\
\text { shoots at } 14-35 \text { days. A marked } \\
\text { reduction in leaf size/area during } \\
\text { flowering. }\end{array}$ & $\begin{array}{l}\text { Kaur et al., 2014, } \\
2015\end{array}$ \\
\hline D. latiflorus & Inflorescences & $\begin{array}{l}\mathrm{MS}+0.1-1.0 \mathrm{mg} / \mathrm{L} \\
\mathrm{TDZ} ; \mathrm{MS}+1 \mathrm{mg} / \mathrm{L} \mathrm{BA} ; \\
\mathrm{MS}+1 \mathrm{mg} / \mathrm{L} \mathrm{ZT}\end{array}$ & $\begin{array}{l}21 \text { days to } 8 \\
\text { months }\end{array}$ & Flower organs normal; pollen sterile. & Lin et al., 2007b \\
\hline D. strictus & Seedling & $\begin{array}{l}1 / 2 \mathrm{MS}+2 \% \text { sucrose } \\
+0.5-1.0 \mathrm{mg} / \mathrm{L} \mathrm{TDZ}\end{array}$ & 2 months & $\begin{array}{l}\text { Anthers protruded only partially. } \\
\text { Gynoecium remained within. Anthers } \\
\text { failed to dehisce. About } 20 \% \text { of anthers } \\
\text { were normal and } 80 \% \text { empty. No seed } \\
\text { set. }\end{array}$ & Singh et al., 2000 \\
\hline
\end{tabular}

MS, Murashige and Skoog medium; 2,4-D, 2,4-dichlorophenoxyacetic acid; BPA, N-Benzyl-9-(2-tetrahydropyranyl) adenine; CW, coconut water.

\section{FERTILITY OF IN VITRO-INDUCED FLOWERS}

Seeds could be obtained from in vitro flowers of B. arundinacea, D. brandisii, B. vulgaris, D. giganteus, and D. strictus (Nadgauda et al., 1990, 1997; Rout and Das, 1994). While D. strictus could produce fertile pollen grains (Singh et al., 2000), in vitro anthers of B. edulis could not (Lin and Chang, 1998; Lin C. S. et al., 2003; Lin et al., 2004a). In B. edulis, the effects of different plant growth regulators on fertility were analyzed. Although auxin treatments promoted anther emergeance outside of glumes, no fertile pollen or seeds were obtained (Lin et al., 2004b). During normal in vivo flowering, D. strictus and B. multiplex have good fertility and easily produce seeds (Nadgauda et al., 1993; Yuan et al., 2011), but there is no report of seed set in Bambusa edulis, reflective of the in vitro results. Therefore, we speculate that the differential fertility in vitro may be related to genetic characteristics of the bamboo species. There is evidence that B. edulis is an intergenus hybrid between Bambusa and Dendrocalamus (Ye, 2010; Zheng, 2014), meaning that $B$. edulis cannot produce gametes with the correct chromosome number for seed set. Due to its long juvenility, it is difficult to conduct cytogentics in bamboo using reproductive organs, such as anthers. Therefore, most karyotyping has been conducted using root tips (Chen R. Y., 2003), although these experiments may have resulted in unreliable chromosome counts in bamboo.

\section{APPLICATIONS OF BAMBOO IN VITRO FLOWERING-CLONING OF FLOWER-RELATED GENES}

Bamboo flowers produced in vitro provide an important material for flower-related molecular and cell biology studies. D. latiflorus spikelets have been used to identify numerous full-length cDNAs of the flowering-related MADS genes (Chen Y. Y., 2003). From a B. oldhamii cDNA library, 4,470 (floral tissue) and 3,878 (vegetative tissue) ESTs were published (Lin et al., 2010). Using proteomic analysis of bamboo flowers, 128 differentially expressed proteins in floral meristems were identified (Kaur et al., 2015). To do such studies on gene and protein expression in floral organs, flowers must be readily available in sufficient quantity.

With next generation sequencing, it has become easier to investigate non-model plant transcriptomes. One such transcriptome that has been explored is that of the in vitroproduced flowers of $B$. edulis. Using this transcriptome and sequences from a bacterial artificial chromosome (BAC) library, 16 full-length Type II MADS (BeMADS) genes were identified. The gene structures and amino acid sequences were highly similar to rice MADS homologs (77-92\%). Most importantly, all of the predicted proteins contain $\mathrm{M}, \mathrm{I}, \mathrm{K}$, and C domains, definitive of type II MADS (Shih et al., 2014). When the whole genome of moso bamboo was published (Peng et al., 2013), 
34 MADS genes were identified (Peng et al., 2013; Cheng et al., 2017). However, the protein lengths and exon numbers were unlike the other Poaceae MADS. Five genes did not have the M domain (PheMADS56-4, PheMADS21, PheMADS14, PheMADS29, and PheMADS90; Cheng et al., 2017), while others were very short and contained only the M domain (PheMADS1, PheMADS5, PheMADS64, PheMADS65; Cheng et al., 2017). Thus far it is unknown whether these differences are due to the starting materials (DNA from in vivo flowers in Cheng et al., 2017 vs. RNA from in vitro flowers in Shih et al., 2014).

Because MADS proteins are transcription factors, they will form complexes that go to the nucleus. However, most fluorescently tagged BeMADS proteins cannot enter the nucleus when expressed in either Arabidopsis protoplasts or in bamboo leaves, but can when expressed in lemmas (Shih et al., 2014). This indicated that correct results can only be shown in the correct materials. Therefore, in vitro bamboo flowers are very important for investigations into bamboo reproduction.

\section{MOVING FORWARD}

Due to the flowering characteristics unique to bamboo (long juvenile phase, mass flowering, and death after flowering), establishment of controllable in vitro bamboo flowering is absolutely required to facilitate timely and effective bamboo breeding. While only self-crosses have thus far successfully produced seeds in vitro (Nadgauda et al., 1990), advances in technology, new induction protocols, or alternative hybridization strategies can further the realization of this goal. For example, $D$. latiflorus and B. edulis plantlets induced to flower in vitro were successfully transferred to the greenhouse, where they continued flowering (Zhang and Wang, 2001; Lin C. C. et al., 2003; Lin et al., 2005). Perhaps parental bamboo accessions could be induced to flower in vitro and transplanted to the greenhouse for further hybridization with other bamboos that are flowering, whether they were induced in vitro or in vivo. This transplantion strategy avoids the limitations of in vitro hybridization, such as high humidity or low wind- or insect-mediated pollination rates. In vitro flowers can also be maintained in tissue culture to preserve those flowering bamboos that cannot survive in the field. Compared with bamboo vegetative tissues, it is easier to establish bamboo reproductive tissues in a tissue culture system (Lin and Chang, 1998).

Furthermore, our study of bamboo flowering indicated that the use of standard model plant material (ex. Arabidopsis) gives

\section{REFERENCES}

Ansari, S. A., Kumar, S., and Palanisamy, K. (1996). Peroxidase activity in relation to in vitro rhizogenesis and precocious flowering in Bambusa arundinacea. Curr. Sci. 71, 358-359.

Bhattacharya, S., Das, M., Bar, R., and Pal, A. (2006). Morphological and molecular characterization of Bambusa tulda with a note on flowering. Ann. Bot. 98, 529-535. doi: 10.1093/aob/mcl143

Bhattacharya, S., Ghosh, J. S., Das, M., and Pal, A. (2009). Morphological and molecular characterization of Thamnocalamus spathiflorus misleading results for bamboo (Shih et al., 2014). While many bamboo flower-related genes have been identified via genomics, the mechanisms of flowering, the expression of floral genes and proteins, and other functional analyses must be done in bamboo reproductive tissues. Stable and readily available sources of in vitro reproductive tissues offer many advantages for further experiments such as genetic transformation.

As the situation stands today, in vitro flowering in bamboo is limited to sympodial bamboos, and only $B$. edulis has thus far been investigated systematically (Lin and Chang, 1998; Lin C. C. et al., 2003). This is a challenge, but our research community hopes to apply the knowledge and techniques reviewed above to further develop tissue culture and in vitro flowering protocols for monopodial bamboos, especially for moso bamboo, which has a longer juvenile phase and is the most important monopodial bamboo species for the bamboo industry in subtropical and temperate regions. Furthermore, the work outlined above represents the current state from which researchers can refine floral induction protocols to predictably induce fertile in vitro bamboo flowers.

\section{AUTHOR CONTRIBUTIONS}

CSL organized and prepared this manuscript. JLY, JJY, CSL, and XPG contributed to the writing.

\section{FUNDING}

This work was supported by the Natural Science Foundation of China (31500551); the Fundamental Research Funds for the Central Non-profit Research Institute of Chinese Academy of Forestry (CAFYBB2016QB008); Zhejiang Science and Technology Major Program on Agricultural New Variety Breeding (2016C02056-8); and the Fundamental Research Funds for the Central Non-profit Research Institute of Subtropical Forestry-Chinese Academy of Forestry (RISF2014001) to JLY. This work was supported by Ministry of Science and Technology, Taiwan (105-2313-B-001-007-MY3), and Academia Sinica, Taiwan, to CSL.

\section{ACKNOWLEDGMENTS}

We thank Anita K. Snyder and Miranda Loney for English editing.

subsp. spathiflorus at population level. Plant Syst. Evol. 282, 13-20. doi: 10.1007/s00606-008-0092-1

Chambers, S. M., Heuch, J. H. R., and Pirrle, A. (1991). Micropropagation and in vitro flowering of the bamboo Dendrocalamus hamiltonii Munro. Plant Cell Tissue Organ Cult. 27:45. doi: 10.1007/BF000 48205

Chen, R. Y. (2003). Chromosome Atlas of Major Economic Plants Genome in China: IV. Beijing: Science Press.

Chen, Y. Y. (2003). Isolation and Evo-devo Genetics of in Vitro Flower Development Related Genes from Dendrocalamus latiflorus (Gramineae: Bambusoideae). 
Dissertation/doctor's, Kunming Institute of Botany; Chinese Academy of Science, Kunming.

Cheng, Z., Ge, W., Li, L., Hou, D., Ma, Y., Liu, J., et al. (2017). Analysis of MADS-box gene family reveals conservation in floral organ $A B C D E$ model of moso bamboo (Phyllostachys edulis). Front. Plant Sci. 8:656. doi: 10.3389/fpls.2017.00656

Feng, S. J., Xu, Y. M., Guo, C., Zheng, J., Zhou, B., Zhang, Y., et al. (2016). Modulation of miR156 to identify traits associated with vegetative phase change in tobacco (Nicotiana tabacum). J. Exp. Bot. 67, 1493-1504. doi: $10.1093 / \mathrm{jxb} / \mathrm{erv} 551$

Gielis, J. (1999). "Micropropagation and in vitro flowering of temperate and tropical bamboos," in Biotechnology and Plant Protection in Forestry Sciences, eds S. P. Raychaudhuri, K. Maramorosch (Boca Raton, FL: Science Publishers, Inc.), $13-38$.

Hassan, A. A. E., and Debergh, P. (1987). Embryogenesis and plantlet development in the bamboo Phyllostachys viridis (Young) McClure. Plant Cell Tissue Organ Cult. 10, 73-77. doi: 10.1007/BF00037499

Ho, C. W., and Chang, W. C. (1998). In vitro flowering of albino bamboo (Bambusa oldhamii Munro) regenerants derived from an eleven- year old embryogenic cell line. Acta Horticult. 461, 433-438. doi: 10.17660/ActaHortic.1998. 461.50

Huijser, P., and Schmid, M. (2011). The control of developmental phase transitions in plants. Development 138, 4117-4129. doi: 10.1242/dev. 063511

Janzen, D. H. (1976). Why bamboos wait so long to flower. Ann. Rev. Ecol. Syst. 7, 347-391. doi: 10.1146/annurev.es.07.110176.002023

John, C. K., and Nadgauda, R. S. (1999). Review in vitro-induced flowering in bamboos. In Vitro Cell. Dev. Biol. Plant 35, 309-315. doi: 10.1007/s11627-999-0040-y

Joshi, M., and Nadgauda, R. S. (1997). Cytokinins and in vitro induction of flowering in bamboo: Bambusa arundinacea (Retz.) Wild. Curr. Sci. 73, 523-526.

Kaur, D., Dogra, V., Thapa, P., Bhattacharya, A., Sood, A., and Sreenivasulu, Y. (2015). In vitro flowering associated protein changes in Dendrocalamus hamiltonii. Proteomics 15, 1291-1306. doi: 10.1002/pmic.201 400049

Kaur, D., Thapa, P., Sharma, M., Bhattacharya, A., and Sood, A. (2014). In vitro flowering- a system for tracking floral organ development in Dendrocalamus hamiltonii Nees et Arn. ex Munro. Indian J. Exp. Biol. 52, 825-834.

Li, Z., and Denich, M. (2004). Is Shennongjia a suitable site for reintroducing giant panda: an appraisal on food supply. Environmentalist 24, 165-170. doi: 10.1007/s10669-005-6050-3

Lin, C. C., Lin, C. S., and Chang, W. C. (2003). In vitro flowering of Bambusa edulis and subsequent plantlet survival. Plant Cell Tissue Organ Cult. 72, 71-78. doi: 10.1023/A:1021281217589

Lin, C. S. (1998). Tissue Culture and In vitro Flowering of Bambusa edulis. Dissertation/doctor's, National Taiwan University, Taiwan.

Lin, C. S., and Chang, W. C. (1998). Micropropagation of Bambusa edulis through nodal explants of field-grown culms and flowering of regenerated plantlets. Plant Cell Rep. 17, 617-620. doi: 10.1007/s002990050453

Lin, C. S., Chen, C. T., Lin, C. C., and Chang, W. C. (2003). A method for inflorescence proliferation. Plant Cell Rep. 21, 838-843. doi: 10.1007/s00299-003-0571-3

Lin, C. S., Kalpana, K., Chang, W. C., and Lin, N. S. (2007a). Improving multiple shoot proliferation in bamboo mosaic virus-free Bambusa oldhamii Munro propagation by liquid culture. Hortscience 42, 1243-1246.

Lin, C. S., Liang, C. J., Hsaio, H. W., Lin, M. J., and Chang, W. C. (2007b). In vitro flowering of green and albino Dendrocalamus latiflorus. New Forests 34, 177-186. doi: 10.1007/s11056-007-9045-8

Lin, C. S., Lin, C. C., and Chang, W. C. (2004a). Effect of thidiazuron on vegetative tissue-derived somatic embryogenesis and flowering of bamboo Bambusa edulis. Plant Cell Tissue Organ Cult. 76, 75-82. doi: 10.1023/A:1025848016557

Lin, C. S., Lin, C. C., and Chang, W. C. (2005). Shoot regeneration, reflowering and post flowering survival in bamboo inflorescence culture. Plant Cell Tissue Organ Cult. 82, 243-249. doi: 10.1007/s11240-005-0 883-9
Lin, C. S., Tseng, M. C., Hong, P. I., and Chang, W. C. (2006). Albino inflorescence proliferation of Dendrocalamus latiflorus. In Vitro Cell. Dev. Biol. Plant 42, 331-335. doi: 10.1079/IVP2006786

Lin, C. S., Vidmar, J., and Chang, W. C. (2004b). Effects of growth regulators on inflorescence proliferation of Bambusa edulis. Plant Growth Regul. 43, 221-225. doi: 10.1023/B:GROW.0000045980.48099.7c

Lin, X. C., Chow, T. Y., Chen, H. H., Liu, C. C., Chou, S. J., Huang, B. L., et al. (2010). Understanding bamboo flowering based on largescale analysis of expressed sequence tags. Genet. Mol. Res. 9, 1085-1093. doi: 10.4238/vol9-2gmr804

McClure, F. A. (1966). The Bamboos: A Fresh Perspective. Cambridge: Harvard University Press.

Mudoi, K. D., Saikia, S. P., Goswami, A., Gogoi, A., Bora, D., and Borthakur, M. (2013). Micropropagation of important bamboos: a review. Afri. J. Biotech. 12, 2770-2785. doi: 10.5897/AJB12.2122

Nadgauda, R. S., John, C. K., and Mascarenhas, A. F. (1993). Floral biology and breeding behavior in the bamboo Dendrocalamus strictus Nees. Tree Physiol. 13, 401-408. doi: 10.1093/treephys/13.4.401

Nadgauda, R. S., John, C. K., Parasharami, V. A., Joshi, M. S., and Mascarenhas, A. F. (1997). A comparison of in vitro with in vivo flowering in bamboo: Bambusa arundinacea. Plant Cell Tissue Organ Cult. 48, 181-188. doi: 10.1023/A:1005800700024

Nadgauda, R. S., Parasharami, V. A., and Mascarenhas, A. F. (1990). Precocious flowering and seeding behaviour in tissue-cultured bamboos. Nature 344, 335-336. doi: 10.1038/344335a 0

Nag, S. (1999). Bamboo, rats and famines: famine relief and perceptions of British paternalism in the Mizo Hills (India). Environ. History. 5, 245-252. doi: $10.3197 / 096734099779568317$

Pei, H. Y., Lin, X. C., Fang, W., and Huang, L. C. (2011). A preliminary study of somatic embryogenesis of Phyllostachys violascens in vitro. Chin. Bull. Bot. 46, 170-178. doi: 10.3724/SP.J.1259.2011.00170

Peng, Z., Lu, Y., Li, L., Zhao, Q., Feng, Q., Gao, Z., et al. (2013). The draft genome of the fast-growing non-timber forest species moso bamboo (Phyllostachys heterocycla). Nat. Genet. 45, 456-461. doi: 10.1038/ ng. 2569

Prutpongse, P., and Gavinlertvatana, P. (1992). In vitro micropropagation of 54 species from 15 genera of bamboo. HortScience 27, 453-454.

Ramanayake, S. M., Wanniarachchi, W. A., and Tennakoon, T. M. (2001). Axillary shoot proliferation and in vitro flowering in an adult giant bamboo, Dendrocalamus giganteus Wall. Ex Munro. In Vitro Cell. Dev. Biol. Plant 37, 667-671. doi: 10.1007/s11627-001-0116-9

Rout, G. R., and Das, P. (1994). Somatic embryogenesis and in vitro flowering of 3 species of bamboo. Plant Cell Rep. 13, 683-686. doi: 10.1007/BF002 31624

Sarma, H., Sarma, A. M., Sarma, A., and Borah, S. (2010). A case of gregarious flowering in bamboo, dominated lowland forest of Assam, India: phenology, regeneration, impact on rural economy, and conservation. J. Forest Res. 21, 409-414. doi: 10.1007/s11676-010-0090-3

Shih, M. C., Chou, M. L., Yue, J. J., Hsu, C. T., Chang, W. J., Ko, S. S., et al. (2014). BeMADS1 is a key to delivery MADSs into nucleus in reproductive tissues-De novo characterization of Bambusa edulis transcriptome and study of MADS genes in bamboo floral development. BMC Plant Biol. 14:179. doi: 10.1186/1471-2229-14-179

Singh, M., Jaiswal, U., and Jaiswal, V. S. (2000). Thidiazuron-induced in vitro flowering in Dendrocalamus strictus Nees. Curr. Sci. 79, 1529-1530.

Singh, S. R., Singh, R., Kalia, S., Dalal, S., Dhawan, A. K., and Kalia, R. K. (2013). Limitations, progress and prospects of application of biotechnological tools in improvement of bamboo-a plant with extraordinary qualities. Physiol. Mol. Bio. Plant 19, 21-41. doi: 10.1007/s12298-012-0147-1

Wang, G., Ding, Y., Huang, M., and Wang, M. (2005). Investigation on tissue culture of some ornamental bamboos. Sci. Sinica 41, 51-55. doi: 10.3969/j.issn.1000-6567.2002.02.002

Wendling, I., Trueman, S. J., and Xavier, A. (2014a). Maturation and related aspects in clonal forestry-Part I: concepts, regulation and consequences of phase change. New Forests 45, 449-471. doi: 10.1007/s11056-0149421-0 
Wendling, I., Trueman, S. J., and Xavier, A. (2014b). Maturation and related aspects in clonal forestry-part II: reinvigoration, rejuvenation and juvenility maintenance. New Forests 45, 473-486. doi: 10.1007/s11056-014-9415-y

Ye, J. (2010). A Preliminary Study on the Hybridization Origin of Bambusa and Bambusa subgen. Dendrocalamopsi. Master's dissertation, Chinese Academy of Science, Beijing.

Yuan, J. L., Gu, X. P., Yue, J. J., Ma, N. X., and Chen, Y. T. (2011). Flowering biology and crossing of Bambusa multiplex. Sci. Silv. Sin. 47, 61-66. doi: 10.11707/j.1001-7488.20110810

Yuan, J. L., Yue, J. J., Wu, X. L., and Gu, X. P. (2013). Protocol for callus induction and somatic embryogenesis in moso bamboo. PLoS ONE 8:e81954. doi: 10.1371/journal.pone.0081954

Zhang, G. C., and Wang, Y., X. (2001). Preliminary study on flowering of tube bamboo seedling. J. Bamboo Res. 20, 1-4. doi: 10.3969/j.issn.1000-6567.2001.01.001
Zheng, C., H. (2014). Speciation of Bambusa-Dendrocalamus-Gigantochloa (BDG) complex-Hybridization revealed by Molecular Evidence. Dissertation/doctor's, Chinese Academy of Science, Beijing.

Conflict of Interest Statement: The authors declare that the research was conducted in the absence of any commercial or financial relationships that could be construed as a potential conflict of interest.

Copyright (C) 2017 Yuan, Yue, Gu and Lin. This is an open-access article distributed under the terms of the Creative Commons Attribution License (CC BY). The use, distribution or reproduction in other forums is permitted, provided the original author(s) or licensor are credited and that the original publication in this journal is cited, in accordance with accepted academic practice. No use, distribution or reproduction is permitted which does not comply with these terms. 